\title{
Chapter 21 \\ The Tensions Between Well-being \\ and Sustainability. Well-being \\ and Sustainability Around 2010
}

\author{
Harry Lintsen and Frank Veraart
}

\begin{abstract}
Contents
21.1 The Netherlands as a Temporary Global Leader in Climate Policy.............................. 460

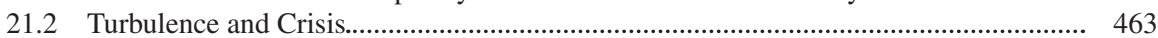

21.2.1 Tense Years: 1970 - 1990.................................................................................... 463

21.2.2 The Dynamic Midfield: Breakdown and Reconstruction............................... 464

21.2.3 The National Government: In Search of a New Role ......................................... 466

21.2.4 The Business Community: In Search of Its Own Responsibility.................... 467

21.2.5 Toward a New Order and New Approaches After 1990................................ 469

21.3 The Monitor for 2010: Development of Well-being and Sustainability....................... 472

21.3.1 Perspective 1970: Progress....................................................................................... 472

21.3.2 Perspective 2010: New Issues........................................................................... 473

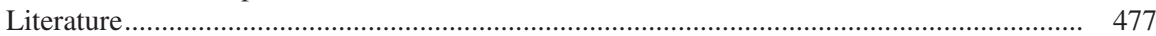

\begin{abstract}
This chapter describes, first, the development of well-being between 1970 and 2010 from the perspective of the efforts of the societal midfield, the national government, and the business community. In the second place, the situation around 2010 is evaluated from the perspective of 1970 and a present-day perspective. From the perspective of 1970 material welfare and well-being have developed in a positive sense between 1970 and 2010. Problematic from this perspective is the increase in criminality and unemployment. In the Netherlands the crisis of nature and environment seems to be past its deepest point.

The present-day perspective is described using the position of the Netherlands in European rankings for different themes and indicators. It confirms what has been said above in previous analyses: the Netherlands has a high quality of life. But this can be contested for the chances for future generations, especially in relation to human and natural capital. In addition, the Netherlands is more than ever intertwined with international supply chains for her resources and energy. In this way the Netherlands has displaced a part of its sustainability problems to foreign lands. On the other hand, international supply chains - as in the meat sector - have led to more landscape damage and environmental problems within the Netherlands.
\end{abstract}

Keywords Midfield · National government - Business community · Environment Sustainability $\cdot$ Monitor $\cdot$ Tradeoff 


\title{
21.1 The Netherlands as a Temporary Global Leader in Climate Policy
}

\begin{abstract}
What we are presently experiencing is not the destruction of the earth in one blow, but in a silent drama. Our world suffers from deforestation, desertification, pollution and the poisoning of air, soil and water, extinction of animal and plant species, erosion of the ozone layer that serves to protect us from dangerous radiation, and an increase in temperature with threatening consequences, such as sea-level rise. Slowly the earth is dying and the unimaginable - the end of life itself - is nonetheless becoming imaginable. ${ }^{1}$
\end{abstract}

With these sombre words Queen Beatrix opened her 1988 Christmas Speech. By the end of the 1980s it looked like environmental problems were accumulating and increasing in scope. Well-being with respect for nature, the environment and climate were the challenges for the period between 1970 and 2015.

In 1988 the National Institute for Public Health and Environment (RIVM) had published the Netherlands' first future study on the environment, Concerns for Tomorrow (Zorgen voor Morgen). Recommendations by the RIVM and by the 1987 World Commission on Environmental Development, chaired by Gro Harlem Brundlandt, inspired a first National Environmental Plan. This was broadly supported by the government. Despite this, Prime Minister Ruud Lubbers' second cabinet fell due to several of the Plan's proposals: the elimination of the default tax restitution for costs of commuting and an increase in excise tax on diesel.

In the 1989 elections, almost all the party platforms prominently flagged plans for sustainable development. The environment had captured the popular imagination. No less than $42 \%$ of the electorate considered this the most important issue. Brundlandt's approach in particular, in which sustainable development and economic growth were considered compatible, found favour among political parties. Wim Kok, the leader of the Labour Party, promised to solve environmental problems 'within one generation.' Targeted levies (ecotax) and regulations would encourage sustainable behaviours. The Christian Democrats (CDA) and the Liberals (VVD) focussed especially on the emerging concern for the climate problem. Candidate (and incumbent prime-minister) Lubbers (CDA) announced an 8\% reduction in carbon dioxide $\left(\mathrm{CO}_{2}\right)$ in the coming cabinet term. The VVD published an 'action plan for the protection of the atmosphere.'2 But policy for the climate problem was relatively new. The way this issue was dealt with reveals the then current political and societal order and its ruling ambitions.

On November 6 and 7, 1989, environment ministers from 68 countries assembled at the Dutch seaside resort of Noordwijk to discuss the contours of a global climate treaty. The plans for this meeting had arisen in 1988 in the course of the Toronto Conference on the Changing Atmosphere. At that conference it was also

\footnotetext{
${ }^{1}$ Christmas Address 1988, Koning Beatrix cited in Carla van Baalen et al., eds., Koning Beatrix aan het Woord, 25 Jaar Troonredes, Officiële Redevoeringen en Kersttoespraken (Den Haag: Sdu Uitgeverij, 2005), 445.

${ }^{2}$ W. Duyvendak, Het Groene Optimisme, Het Drama van 25 Jaar Klimaatpolitiek (Amsterdam: Bert Bakker, 2011), 39-52.
} 
decided to promote additional research in this area and for this purpose to found the International Panel on Climate Change (IPCC).

The meeting in Noordwijk took place during the final two days of Ed Nijpels' term as minister of the environment. He proudly announced that 'The Netherlands wants to be the leader in the area of the climate treaty in spe, and with respect to reduction of $\mathrm{CO}_{2}$ pollution.' ${ }^{3}$ This was the first time that climate change and measures to reduce $\mathrm{CO}_{2}$ emissions had been spoken of at the ministerial level.

The issue was also remarkable because of the ambivalent attitude of the environmental movement. The Foundation for Nature and the Environment (Stichting Natuur en Milieu) had been invited to the Noordwijk conference only at the very last minute. It submitted a proposal to reduce $\mathrm{CO}_{2}$ emissions by $20 \%$ by the year 2000. At the same time it argued that nuclear energy 'could not be an alternative in the struggle against the greenhouse effect. ${ }^{4}$ Nuclear energy had been one of the big environmental issues of the 1970s and 1980s. The Chernobyl disaster in 1986 had closed the door on this option, or so it seemed. But with growing concern for the climate problem, the environmental movements were concerned lest nuclear energy threatened to become an option again.

In the wake of the conference newspapers headlined: 'Disappointment after climate conference. Great powers block solid agreements.' The Dutch hosts proved unable to forge a climate treaty at the Noordwijk meeting. The United States and Japan, in particular, first wanted to await results of the IPCC investigations. The meeting did settle on an agenda for international climate agreements, such as the different roles of developed and developing countries, the importance of forests and targets for levels of emission reduction with 1990 as a reference year. ${ }^{5}$

The meeting occurred at a peculiar moment in time for the Netherlands. Due to the transfer of political power, the election period of 1989 marked the temporary high-water mark of Dutch societal and political concern for environment and sustainability in the period 1970-2015. Throughout the 1980s, the country had seemed to be buried under an ever-growing avalanche of environmental problems. After concern about air and water pollution in the early 1970s, a number of "pollution scandals' called attention to the pollution of soil and groundwater. In 1982 there were 4253 reports of pollution nationwide, of which 1246 were classified as highly urgent. ${ }^{6}$

In the same period there were growing concerns about acidification. These were originally focussed on the emission of sulphur dioxide and the trans-border problem

\footnotetext{
${ }^{3}$ 'Nijpels hoopt op afspraken tijdens milieuconferentie', NRC 4-11-1989, 7.

4 'Milieuconferentie begint in sfeer van onenigheid, Nederland vraagt om hulp voor Derde Wereld' in Nederlands dagblad 07-11-1989.

${ }^{5}$ Duyvendak, Het Groene Optimisme, 53-54.

${ }^{6}$ Investigations into the scope of the problems gained momentum after the pollution scandal in Lekkerkerk (1980). A first overview was prepared at the behest of Minister L. Ginjaar for the interim-regulations on soil-decontamination. See Klaas Bouwer, Jacques Klaver, and Marianne de Soet, Nederland Stortplaats, een Milieukundig en Geografische Visie op het Afvalprobleem (Nijmegen: Ekologische uitgeverij, 1983), 64-65.
} 


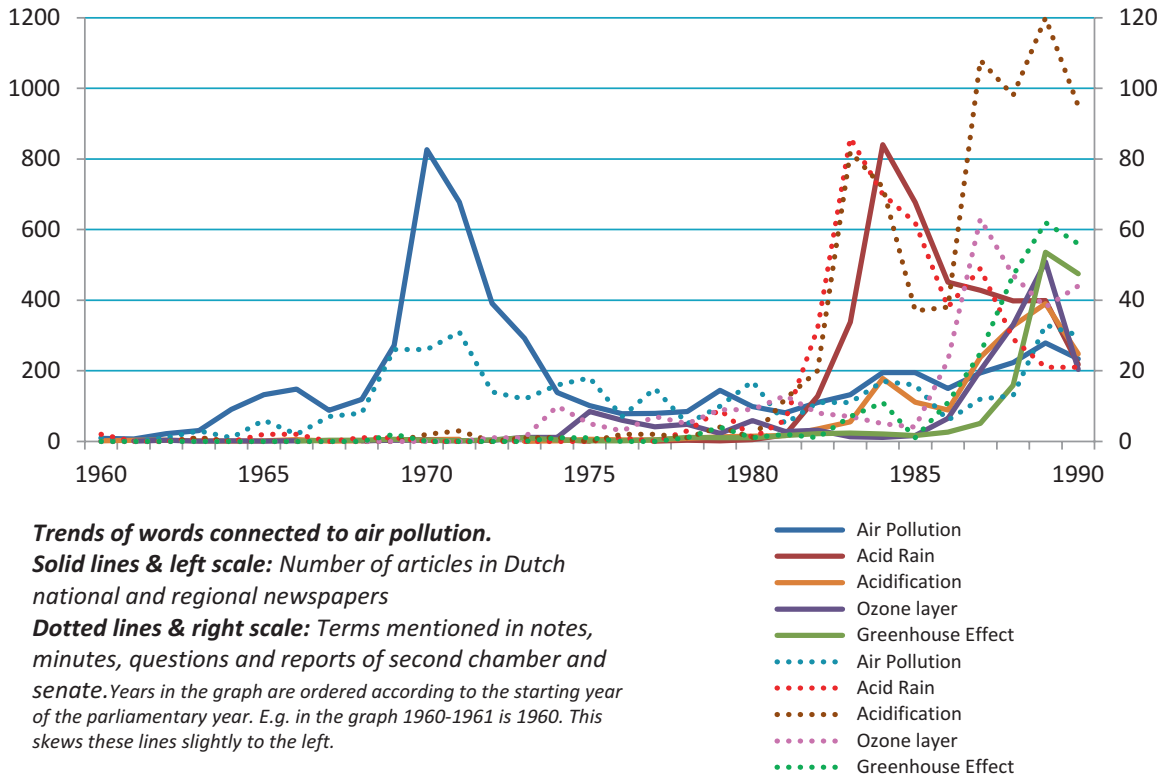

Graph 21.1 Topics related to air pollution in Dutch newspapers and in the Transactions of the Second Chamber of Parliament 1960-1990

Note 1: after 1990 the newspaper data set is incomplete

Note 2: Regarding the newspaper data it may be the case that newspaper articles appearing in both regional and national newspapers are counted twice. In the parliamentary and senate notes, minutes and reports there is a distinction between loose remarks and full reports. The content of these articles, notes, etc. was not checked. Articles might, for example, review foreign news or suffer from other anomalies. This is especially problematic with small numbers

Source: Royal Library - online Newspaper database Delpher-Kranten (www.delpher.nl) and online database governmental notes of parliament and senate (www.statengeneraaldigitaal.nl)

of acid rain. With improved knowledge and more accurate measurements, acidification due to agricultural ammonia emissions also became part of the picture. ${ }^{7}$ The latter led to increased interest in eutrophication of the soil by nitrogen and phosphorous deriving from agriculture and households. By the end of the 1980s the international problems of the erosion of the ozone layer and climate change had become prominent issues in the press and in politics (see Graph 21.1).

With its National Environmental Policy Plan and the debate on climate problems the Netherlands regarded itself as world leader in environmental policy. Was this justified? And did it retain this position? What happened to the attention for climate and environment after 1990?

\footnotetext{
${ }^{7}$ Ed Buijsman, 'Gisteren, Vandaag, Morgen, Een Terugblik op het Probleem van Zure Regen,' Studium 4 (2008): 251-68; G.H. Dinkelman, Verzuring en Broeikaseffect, de Wisselwerking tussen Problemen en Oplossingen in het Nederlandse Luchtverontreinigingsbeleid (1970-1994) (Universiteit van Amsterdam, 1995).
} 


\subsection{Turbulence and Crisis}

\subsubsection{Tense Years: 1970 - 1990}

In the 1970 s and 1980s the Netherlands had more worries than only those concerning environment and sustainability. The economy was in bad shape. The economic wonder of the 1950s and 1960s with its almost unbroken growth had begun to lose momentum. Increasing wage levels and prices in the course of the 1960s had already compromised Dutch competitiveness. ${ }^{8}$ The expansion of world trade ground to a halt in response to extreme fluctuations in currency markets, stock exchanges and markets for raw materials. A wave of global inflation flooded the economy. The first oil crisis of 1973 brought further wage and price increases. ${ }^{9}$ The business community suffered. Turnover stagnated. Profits declined. The proportion of those employed in industry declined drastically and unemployment rose. After the second oil crisis of 1978 the economic situation declined even more dramatically, to recover only at the end of the 1980s.

The economic situation was hardly favourable to measures aimed at improving the environment or sustainability. Despite this, the government maintained that an environmental policy including investments by the business community was essential in order to change existing 'dirty' production processes and to repair past environmental damage. However this created even more problems for the business community. It complained loudly about the costs of the environmental measures.

Environmental policy was not the only cause of increasing costs for the business community. During the 1970 s the welfare state also expanded. ${ }^{10}$ The General Law on Labour Incapacity (Algemene Arbeidsongeschiktheidswet) insured not only employed workers but also non-employed workers against the consequences of unfitness for work. The minimum wage and the budgets for social security were increased. The number of Netherlanders dependent on social services increased, in part due to growing unemployment. The minimum wage and welfare benefits were coupled to wage levels in the market sector. This all contributed to increased costs for business: higher wages and increased taxes and welfare contributions.

The government was itself also confronted with the consequences of its policies. In the course of the 4 years after 1973, government expenses increased from $45 \%$ of the Gross Domestic Product to 51\%. After 1974 the state budget showed a chronic deficit. The gradual decline in the magnitude of the national debt came to a halt in 1977.

Fundamental tensions among the welfare state, the economy and sustainability became apparent in the 1970s. By expanding welfare services, the government

\footnotetext{
${ }^{8}$ J.L van Zanden and R.T. Griffiths, Economische geschiedenis van Nederland in de $20^{\mathrm{e}}$ eeuw (Aula, Utrecht 1989), 48-49.

${ }^{9}$ Van Zanden and Griffiths, Economische geschiedenis van Nederland, 255-258.

${ }^{10}$ See for the following: J. Peet en E. Nijhof, Een voortdurend experiment. Overheidsbeleid en het Nederlandse bedrijfsleven (Uitgeverij Boom, Amsterdam 2015), 199-205.
} 
hoped to shore up the purchasing power of the unemployed, the ill and the poor and in this way to stimulate the economy. If that appeared still to work in the 1970s, it proved impossible to maintain in the long run. Government largesse was financed by proceeds from the sale of natural gas, by government loans and by an increase in the budget deficit. But workers stuck by their hard-won rights. Massive protests followed on a proposal to terminate automatic price compensation for wage earners in the market sector. Environmental groups demanded rigorous environmental measures. Employers pointed to the structural economic problems caused by government policy. In many firms profits were inadequate to enable production to continue or to invest in expansion. The business community argued that society was much more concerned with distributing welfare than with creating it.

\subsubsection{The Dynamic Midfield: Breakdown and Reconstruction}

Societal contradictions increased in the 1970s, ultimately leading to an about-face. The economic miracle after the Second World War had exacted offers from the Dutch population. Parsimony ruled the day. There had been little opportunity for consumption. The reconstruction of the country, the modernisation of the economy and the Delta Works had exacted enormous investments. The resulting tensions had been absorbed by the pillarised social structure. The necessary consensus had been created within the pillars, with their organisations in the fields of work, enterprise, education, sport and social life. This is where the shock of modernisation had been absorbed. ${ }^{11}$

But by the second half of the 1960s de-pillarisation had set in. The influence of the church and religion on social life declined. The membership of the confessional parties declined and their political dominance began to wane. This also meant the end of the soundless achievement of a societal consensus. In the course of the 1970s the number of strikes began to increase after a long period of quiescence. Workers' associations increasingly went their own way. Labour contract negotiations and bargaining in the Social-Economic Council no longer 'automatically' led to a consensus.

A new societal midfield emerged but did not replace the pillars. To have done so it would have had to have been less specifically oriented to the issue of the environment. Groups like the national Association for the Preservation of the Wadden Sea (1965), the Foundation for Nature and the Environment (1972) and the Central Action-Committee Rijnmond (1970) were oriented above all to exercising political and administrative influence. Groups like Action Last Hope (1970) and the Association for Environmental Defence (1970) used demonstrations and publicity to

\footnotetext{
${ }^{11}$ K. Schuyt and E. Taverne, 1950. Welvaart in zwart-wit (Den Haag, 2000: Sdu Uitgevers), 40-41.
} 
advance the environmentalist cause. Associations like De Kleine Aarde (1971) and ecologically inspired working communities used concrete examples to try to win the broader public for an environmentally friendlier and energy-conserving lifestyle. ${ }^{12}$

These organisations became highly visible in the collective protest against nuclear energy. In the 1980s they were able to mobilise thousands of people for protest demonstrations at the experimental reactor at Dodewaard and the uranium enrichment facility Urenco in Almelo. ${ }^{13}$ Another broadly supported protest aimed to prevent the closure of the East Scheldt and the expansion of marl mining. In the course of these engagements the environmental movement gradually acquired a new role. They increasingly became sources of information and expertise in the area of environmental technology. This enabled them to make substantive contributions to proposals and solutions.

In the 1980s idealism gave way to pragmatism. In cooperation with governments and the business community, the overthrow of capitalism was abandoned as an aim, to be replaced by a transition to ecological modernisation. This was inspired in particular by the sustainability concept as worked out in the Brundtland report. At the same time the environment became a more central concern for businesses and governments, who found useful partners in the environmental organisations with their new knowledge and expertise. ${ }^{14}$

In the 1980s, strategies of cooperation were reintroduced into the economy. In 1982 representatives of employees and employers, under the benevolent eye of the government, signed the famous 'Wassenaar Agreement.' A long period of polarisation thereby came to an end as a new era of compromise began to take shape. Workers were now prepared to relax wage demands in return for shorter working hours. The expectation was that this would both improve the competitive position of the business community as well as increase employment opportunities. In the same spirit, the relationship between social policy and the economy was redefined. Guarantees of social security were not rejected out of hand, but limited to what was necessary and to what was manageable from an economic and financial point of view. ${ }^{15}$

\footnotetext{
${ }^{12}$ J. Cramer, Milieu (Amsterdam University Press, Amsterdam 2014), 21-22.

${ }^{13}$ In 1980, 15,000 people demonstrated at the Dodewaard nuclear power plant. In 1987, 25,000 people protested against the underground storage of nuclear wastes in Gasselte and 40,000 at the uranium enrichment facility in Almelo. Duyvendak, Het Groene Optimisme, 62.

${ }^{14}$ Cramer, Milieu, 53-54.

${ }^{15}$ Peet en Nijhof, Een voortdurend experiment, 223. At the national level there was the tri-polar consultation among employers, employees and the government. In the 1990s this would become known as the 'polder' model and come to be seen as the basis of the Dutch miracle: a well-oiled economy, growing employment, decreasing budget deficits and a less-costly welfare system. B. Bouwens and J. Dankers, Tussen concurrentie en concentratie. Belangenorganisaties, kartels, fusies en overnames (Uitgeverij Boom, Amsterdam 2012), 205.
} 


\subsubsection{The National Government: In Search of a New Role}

In regard to environment and energy, the government had long pursued a directive policy. The Ministry of Economic Affairs imposed its will on energy policy by advocating a central role for energy conservation and nuclear power. A new ministry, the Ministry of Public Housing and Environmental Hygiene, founded in 1971, developed legal instruments to compel the business community to take environmental measures. ${ }^{16}$ These measures were primarily aimed at managing local environmental pollution, initially of air and water and by the early 1980s of the soil as well. Problems were defined chiefly as public health risks. The policy was inspired by research conducted by the National Institute for Public Water Supply, the Institute for Waste Research, and the National Institute for Public Housing that had been investigating air quality since the 1960s. Norms, permits and subsidies were mobilised to force a reduction of emissions and energy consumption.

At local levels this strategy was certainly successful. End of pipe technologies decreased emissions. ${ }^{17}$ And as far as $\mathrm{SO}_{2}$ emissions were concerned: the transition to natural gas also had an effect. Nonetheless, there was increasing unease about the environment and energy. Policy makers began to focus on biodiversity and damage to the landscape. Problems became more and more global in nature. Acid rain, climate change and destruction of the ozone layer were not limited to the Netherlands. The national government once again had to reconsider its strategy in regard to environmental and energy issues.

The environmental issues were transferred to the newly-formed ministry of Public Housing, Spatial Planning and Environmental Management. At the end of the 1980s, a report, Concerns for Tomorrow (Zorgen voor Morgen) and the National Environmental Policy Plan opted for drastic reductions in the emissions of many substances and the prevention of future environmental damage. Toughening up technical specifications for firms, devices and vehicles was no longer enough. It was necessary to pursue an integral strategy for energy supply, agriculture and traffic and transport. ${ }^{18}$ Spatial planning was also subjected to an integral approach. The

\footnotetext{
${ }^{16}$ H.T. Siraa, A.J. van der Valk and W.L. Wissink, Met het Oog op de Omgeving. Het Ministerie van Volkshuisvesting, Ruimtelijke Ordening en Milieubeheer, 1965-1995 (Den Haag: SDU Uitgeverij, 1995), 244-67.

${ }^{17}$ Cramer, Milieu, 18-19.

${ }^{18}$ Cramer, Milieu, 29-31. The shift in environmental policy can also be interpreted in another way, namely from end of pipe policy to policy based on the precautionary principle to a no-regret policy. The precautionary principle was the point of departure for the policy entailed in the report Concerns for Tomorrow (Zorgen voor Morgen, 1988). A much-used definition states that new technologies may not be implemented without precautions if there is a chance of serious or irreversible damage even when there is no scientific certainty about risks. See, among others: A. Reichow, Effective regulation under conditions of scientific uncertainty: How collaborative networks contribute to occupational health and safety regulation for nanomaterials (Enschede, UT Twente, 2015) (dissertation), 37-38.). The actual application of this approach was often highly problematic and there was political concern about the possible adverse effects on competitiveness of new environmental regulations. In the 1990s the precautionary principle made way for the no regret policy of ecological
} 
first National Nature Policy Plan of 1989 featured the so-called Ecological Main Framework, in which nature zones were connected to one another by means of connective corridors. ${ }^{19}$ The national plans translated into spatial programs like the VINEX (1990-2010) and the Space Memorandum (2004).

Progressive European unification also inspired important changes. This brought with it a uniform set of environmental regulations in the various member states. Environmental regulations now increasingly came from 'Brussels' instead of 'The Hague.' It should be noted that these were partly based on Dutch experience. The Dutch Ecological Main Framework inspired the European ecological network of the Natura 2000 program. ${ }^{20}$ European norms regarding air quality (fine dust norms) bore the mark of the Dutch National Institute for Environmental Management (RIVM) throughout the 1980s and 1990s. ${ }^{21}$

In another respect, too, there was a change of course. The directive policies were gradually abandoned. Government policy now more often than not aimed at cooperation with the business community and the societal organisations. Self-regulation within business sectors was emphasised. In the 1980s the national government was busy re-inventing its societal role. The change of course was also possible thanks to the changing attitude of the business community toward environmental and energy issues.

\subsubsection{The Business Community: In Search of Its Own Responsibility}

Originally the business community reacted defensively and strategically to the criticisms it had to endure as the 'chief suspect' in the environmental crisis. ${ }^{22}$ It delegated representatives to government commissions charged with developing environmental regulations. It arranged representation in the directorates of water

modernisation, such as measures to limit the effects of climate warming. (Jeroen P. van der Sluijs, Rinie van Est, and Monique Riphagen, Room for Climate Debate, Perspectives on the Interaction between Climate Politics, Science and Media (The Hague: Rathenau Instituut, 2010), 18-20.)

${ }^{19}$ Hans van der Cammen and Len de Klerk, Ruimtelijke Ordening, van Grachtengordel tot VinexWijk (Utrecht: Het Spectrum, 2003), 252-53.

${ }^{20}$ See also chapter 18 . The Netherlands, together with Flanders and Germany, were pioneers in the development of ecological networks. In Rob H.G. Jongman, 'Nature Conservation Planning in Europe: Developing Ecological Networks' Landscape and Urban Planning 32 (1995): 196-183. Per Högselius, Arne Kaijser, and Erik van der Vleuten, Europe's Infrastructure Transition, Economy, War, Nature, vol. 4, Making Europe: Technology and Transformations, 1850-2000 (Basingstoke / New York: Palgrave Macmillan, 2016), 261-65.

${ }^{21}$ See also chapter 20; T. Arnoldussen, The Social Construction of the Dutch Air Quality Clash. How Road Expansions Bit the Dust Against Particulate Matter (Eleven International Publishing, The Hague 2016), 125-64.

${ }^{22}$ See for the following among others: $\mathrm{H}$. Lintsen and J. Korsten, De veerkracht van de Brabantse economie. De Kamers van Koophandel en de kracht van netwerken [1840-2015] (Stichting Zuidelijk Historisch Contact \& Uitgeverij Verloren, Hilversum 2017), 134-139. The Chambers of Commerce represent the business community in many environmental issues. 
boards that developed policy on the pollution of surface water. It made an inventory of the problems entrepreneurs ran into due to environmental regulations, the need to process wastes and the associated costs. It for example protested against '... the disproportional increases that are the consequence of the new levies associated with the implementation of the Law on Surface Water Pollution... ${ }^{23}$ But in the course of the 1970 s this attitude began to change.

In the previous decade one could roughly say that in societal consciousness concern for the environment was most highly valued. This was possibly not unjustified as a counterweight to the increased appreciation for the aspect of welfare in the period immediately after the Second World War. It seems to me that the time is now ripe for a balanced approach in weighing these priorities... ${ }^{24}$

In this way the entrepreneur and freshly minted chairman of the Eindhoven Chamber of Commerce, H. Schellens, expressed the feelings of the business community in 1976. At the end of the 1980s, representatives of the business community took an additional step. A sound environmental policy was considered to be highly important for 'the preservation of an attractive residential, working and living environment' and hence also for a favourable climate for attracting new firms. ${ }^{25}$ The new Law on Environmental Management of 1993 thus enjoyed a positive reception. 'The business community is aware of its own environmental responsibility and does not seek to avoid it...,' but it did request from the government 'the necessary room for manoeuvre to operate in this manner. On an international level, too, it was necessary to seek a fit between norms and requirements. ${ }^{26}$ Contacts with the governments were intensified.

In addition to consultations, the business community also undertook its own initiatives in the area of environment and energy. '.... Not only because the government and society have given it an important priority, but precisely also from the viewpoint of efficiency, quality control, cost control, use of raw materials, working conditions, shop floor risks and market image. ${ }^{27}$ Firms set up their own internal environmental care departments or employed external environmental services. ${ }^{28}$

\footnotetext{
${ }^{23}$ Jaarverslag Kamer van Koophandel Eindhoven 1975, 28 en 65.

${ }^{24}$ Jaarverslag Kamer van Koophandel Eindhoven 1975, 68.

${ }^{25}$ Beleidsplan Provinciaal Samenwerkingsorgaan Kamer van Koophandel Noord-Brabant Beleidsplan 1989, 11 in Archief Provinciaal Bureau Kamers van Koophandel in Noord-Brabant, BHIC 1157, map 44.

${ }^{26}$ Jaarverslag Kamer van Koophandel Noordoost Brabant 1993, 27-28. The chamber informed the business community in its area both collectively and individually about the new law and its consequences. In Oss, for example, it cooperated with the municipality. Jaarverslag PSK over de periode 1 juli 1992 tot 1 juli 1992, in Archief Provinciaal Bureau Kamers van Koophandel in Noord-Brabant, BHIC 1157, map 43.

${ }^{27}$ Jaarverslag Kamer van Koophandel Noordoost-Brabant 1991.

${ }^{28}$ Lintsen en Korsten, De veerkracht van de Brabantse economie, 138-139.
} 


\subsubsection{Toward a New Order and New Approaches After 1990}

A more pro-active business community and fewer directive interventions by the government fit perfectly in the new era in which liberalisation of the economy had become the watchword. ${ }^{29}$ The economic crisis at the end of the 1970s and the beginning of the 1980s cleared the way for a reassessment of private initiative in a free market. The American president Ronald Reagan and the British prime minister Margaret Thatcher gave the international example as they advocated privatisation and de-regulation. The government should no longer play an active role in the steering of the economy. State enterprises were better off in private hands. Private firms could in many cases perform government tasks more efficiently.

The Dutch government toed the international line. It sold its shares in companies like KLM and the Hoogoven steel mills and withdrew from public utilities like the postal and telephone services. Suppliers of energy and waste processing facilities were privatised. The government also undertook severe cutbacks and chiselled away at social security. The Competition Law of 1998 sought to create more room for market dynamics. It prohibited agreements among companies to suppress competition, a measure that meant the end of cartel-formation in the Dutch economy. ${ }^{30}$ The dirigiste tradition in agriculture also made way for government at a great distance from this sector. Agriculture increasingly became just another economic sector. But not all forms of societal coordination were abandoned. One mode did fit with the liberal model, namely the covenant. This instrument enjoyed immense popularity in the area of energy and environment.

The government used covenants to create a constituency for environmental goals in the short and long term. ${ }^{31}$ A covenant emerged out of consultations among the government, the business community and societal groups. Out of this came voluntary, but by no means non-committal, agreements - often at the level of a specific branch. These were congruent with general policy frameworks established by the political system. Branch-organisations shouldered part of the responsibility for policy and oversaw the implementation. The government supported progress by providing permits, subsidies and other 'supplementary policy.'32 Environmental organisations partnered with the business community and contributed concrete and realistic solutions.

The shift to self-regulation also stimulated the business community to undertake other initiatives like 'sustainable entrepreneurship' (later also called 'socially responsible entrepreneurship'). Firms pursuing this course formulated a vision of sustainability, coupled this to a corporate strategy, established a monitoring and

\footnotetext{
${ }^{29}$ See for the following: Bouwens and Dankers, Tussen concurrentie en concentratie, 203-207.

${ }^{30}$ The economic-political policy also resulted in the dismantling of long-established coordinating organisations such as the Agricultural Board (Landbouwschap, 2001), the Chambers of Commerce as independent regional organisations (2014) and the industry and product boards (2015).

${ }^{31}$ Bouwens and Dankers, Tussen concurrentie en concentratie, 213-215; Peet and Nijhof, Een voortdurend experiment, 236.

${ }^{32}$ Bouwens en Dankers, Tussen concurrentie en concentratie, 213; Cramer, Milieu, 40-41.
} 
reporting system and infused the vision into their corporate culture. The financial sector followed with sustainable investing. Sustainability funds ranked firms on the basis of their achievements on economic, social and environmental dimensions. ${ }^{33}$

There was also another shift. Policies had long aimed at suppressing emissions of noxious substances. From the 1990s on, prevention became the main strategy: designing production and other processes in such a way that the emission of environmentally polluting substances was kept to a minimum. With 'sustainable entrepreneurship' the focus was on the production process of the individual firm. So-called 'integral chain management' shifted attention from discrete production processes to production-consumption chains and aimed at redesigning the entire chain from an environmentally conscious perspective. ${ }^{34}$

The transition to a preventive and integral approach also had to do with the globalisation of environmental and energy issues. The emergence of new industrial economies in countries like China, Brazil and India extended environmental problems beyond the previously industrialised countries. More than ever, environmental issues were transported to other places ('elsewhere') and as such became a global concern. Two issues dominated the agendas of international organisations and national governments: climate and raw materials.

These issues became prominent in the Netherlands as well. ${ }^{35}$ For example, in 2007 the government set a goal for 2020: a 30\% reduction in $\mathrm{CO}_{2}$ emissions, $20 \%$ energy saving and $20 \%$ sustainable energy, all relative to 1990. An encompassing program called 'Clean and Thrifty' was set up. Nine ministries were involved. Municipalities and provinces signed the climate agreement and made deals with the national government regarding their contributions to the goals. Branch organisations agreed to an overarching covenant and ten sectoral covenants. Funds were made available for research and innovation.

The program was inspired by the transition approach. This went a step further than the integral strategy. A society-wide, long-term vision on sustainability formed the point of departure for short-term actions. All the societal actors had to be involved. There had to be sufficient space for experiments and learning. It was accepted that the course of a transition process could not be fixed beforehand. Actions at the micro-level had to influence structural changes at the meso-level, which also entailed processes at the macro-level. New images of the future revealed the fundamental character of the transition. Changes in the domains of energy and raw materials would form the basis of a third industrial revolution. The social fabric of 2050 would be interwoven with a new economic system that would be based on the re-use of products and resources and the conservation of natural resources.

\footnotetext{
${ }^{33}$ Cramer, Milieu, 63-64.

${ }^{34}$ Cramer, Milieu, 46.

${ }^{35}$ For the following see: Cramer, Milieu, 81-82; 91; 109-111.
} 
Material flows would then become closed cycles and energy sources become renewable. The Netherlands would have to pursue the road to a circular economy. We will deal extensively with this last image in the epilogue to this book.

What were the results of the 'Clean and Thrifty' program? ${ }^{36}$ None of the aims for 2020 in regard to $\mathrm{CO}_{2}$ reduction, energy saving and sustainable energy will be achieved. The feasibility of a reviewed and revised energy agreement signed in 2013 is also in doubt (chapter 20). One of the reasons was that the system of emissions trading ended up a failure. The system was developed at the European level. It gave businesses rights to $\mathrm{CO}_{2}$ emissions and the possibility to trade these rights. It would have encouraged the reduction of $\mathrm{CO}_{2}$ emissions had the price remained at $€ 30-€$ 40 per ton of $\mathrm{CO}_{2}$, but the price dropped to less than $€ 5$ in 2014.

Another important reason was the change in the political climate. After a change of government in 2010, the 'Clean and Thrifty' program was put on the back burner. Terrorism, migrants and economic crises drove sustainability issues to the background. Concern for the environment and sustainability once again became a political choice. According to many in the field, the government did not show itself at its most trustworthy. Subsidy policy changed continually. Governments repeatedly failed to achieve the goals they set. ${ }^{37}$

But relationships in the field had also changed. Citizens lost interest in the environment as new societal issues emerged. The professionalisation of environmentalism also played a role. The environment had become the property of experts in industries, the government and environmental organisations. After the turn of the century a new popular movement emerged that was independent of the established institutions and that developed initiatives like local energy cooperatives and small businesses for sustainable products.

It is within this context that we now evaluate the quality of life in the Netherlands for the last sample date of this book. We do that using the monitor for 2010 and from two perspectives: from the perspective of 1970 and from a present-day perspective.

\footnotetext{
${ }^{36}$ Cramer, Milieu, 82-84.

${ }^{37}$ In October 2017, the Planning Bureau for the Environment, for example, expressed doubts whether the Rutte-III cabinet would be able to meet its own climate goals. The Bureau states: 'The emission goal of $49 \%$ proposed by the Rutte-III cabinet fits with the ambitions of the Paris accord to limit temperature rise to well under 2 degrees. The measures analysed here achieve roughly half of the necessary reduction in emissions. A transition policy is in place but can acquire more momentum. In order to achieve the aimed-for reduction of $49 \%$ in 2030, it will therefore be necessary to work out additional measures in a new climate and energy agreement.' Analyse regeerakkoord Rutte-III: effecten op klimaat en energie (Uitgever: Planbureau voor de Leefomgeving, Den Haag 2017), publicatienummer: 3009, 33.
} 


\subsection{The Monitor for 2010: Development of Well-being and Sustainability}

\subsubsection{Perspective 1970: Progress}

How should well-being and sustainability around 2010 be evaluated from the perspective of 1970? Which themes were then on the societal agenda and what is their present state? We arrive at the following brief summary.

An evaluation from the perspective of 1970 shows a mixed verdict. Material welfare has increased and the inequality between men and women has declined. Netherlanders are older, taller and heavier. Dwellings and facilities are of higher quality. All this with more free time. In these respects the image is positive.

But unemployment levels have, grosso modo, increased. During the economic recession at the end of the 1970s these increased for the first time since the 1930s. After that, unemployment followed the ups and down of the economy. The recessions impacted on social inequality. Due to the lowering of the minimum wage in the 1980s, the chronic pressure on welfare budgets and restructuring of the social security system income inequality grew between 1985 and 1990 and again around the year 2000. ${ }^{38}$

From the perspective of 1970 the participation of the populace in politics is also disappointing. The democratisation of society and the levelling of power differentials were important issues around 1970. In this respect the Netherlands has shown no improvement. Quite the contrary. The Dutch demonstrate less quickly, attend consultation meetings less frequently and have less recourse to political parties. They are, moreover, less frequently members of political parties, trade unions, conservation societies and consumer organisations (in terms of percentage of population). ${ }^{39}$ These trends are not a sign of greater satisfaction, but rather of lower levels of participation and commitment. There is mistrust of politics and dissatisfaction with the existing institutions. ${ }^{40}$ The linkages between politics and social networks were lost with the end of pillarisation. New linkages have yet to emerge in their stead. For example, more Netherlanders are active politically via the internet and more frequently boycott products because they cause environmental damage or involve child labour. In addition there is evidence that small-scale local forms of citizens' initiatives are emerging. The populace certainly appears to be sensitive to

\footnotetext{
${ }^{38} \mathrm{~W}$. Salverda et al., Nederlandse ongelijkheid sinds 198. Loonvorming, overheidsbeleid en veranderde samenstelling van huishoudens (Uitgever: Amsterdam Institute for Advanced Labour Studies/ University of Amsterdam, Amsterdam 2013).

${ }^{39} \mathrm{R}$. Bijl et al. (ed), De sociale staat van Nederland 2015 (Uitgever: Sociaal en Cultureel Planbureau, Den Haag 2015), 221-222.

${ }^{40}$ See among others the following publication, with which we opened this book: P. Schnabel, 'Feiten en gevoel', in: C. van Campen et al. (eds.),Sturen op geluk. Geluksbevordering door nationale overheden, gemeenten en publieke instellingen (Uitgever: Sociaal en Cultureel Planbureau, Den Haag 2012), 17-23.
} 
societal issues but possibly have more faith in their own initiatives than in those of politics and the government.

Concern for the environment and nature seems to have bottomed out and is again on the rise. Local environmental problems have been rigorously dealt with. Nature restoration projects have commenced. The numbers of seals, beavers, badgers and birds of prey - symbolic for the restoration of natural habitats - have increased. But measured against the quantity of all animal species the comeback is still quite modest. In any case, the decline seems to have been arrested.

International and global environmental problems were hardly at issue around 1970. That was not the case for the problems with raw materials that became a major concern in the light of the Report of the Club of Rome. This concern persists, but is now overshadowed by the climate problem.

\subsubsection{Perspective 2010: New Issues}

How should we evaluate the present situation from a present-day perspective? We could look with the gaze of politicians, policy makers, opinion leaders or business leaders. An evaluation could also proceed from the priorities of the Dutch population, as they can be deduced from surveys. Here we choose the approach used by Statistics Netherlands (CBS) in which the situation in the Netherlands is compared with the other countries of the European Union. This is done on the basis of the indicators of the 'well-being monitor' (Table 21.1). These provide an image of important societal issues. We assume that the political and policy establishment also considers them important. We also assume that the Netherlands is doing well if it occupies a place near the top of the EU rankings. If the Netherlands finds itself near the bottom, we regard the situation as problematic. ${ }^{41}$

According to the monitor, the quality of life 'here and now' is, by European standards, very high. The Netherlands is in good shape with respect to material welfare, health, life-expectancy, housing, free time and various other indicators for the personal situation. However, after making an inventory of all relevant indicators, Statistics Netherlands and the three Dutch planning bureaus offer the following caveat: '... we create the quality of life in the here and now in a manner that makes it difficult for future generations to create welfare. ${ }^{42}$ The present generation partly shifts the solution of the sustainability problems it has created to the future. The bureaus also note that the present welfare of the Netherlands contributes to sustainability problems in foreign countries (see below).

\footnotetext{
${ }^{41}$ An approach of this nature can be found in Monitor Duurzaam Nederland 2011 (Centraal Bureau voor de Statistiek, Den Haag/Heerlen 2011) en Monitor Duurzaam Nederland 2014. Indicatorenrapport ( Centraal Bureau voor de Statistiek, Den Haag/Heerlen 2014).

${ }^{42}$ Monitor Duurzaam Nederland 2011, 51.
} 
Table 21.1 Dashboards well-being and sustainability in 2010 from the perspectives of 1970 and a present-day perspective (EU position)

\begin{tabular}{|c|c|c|c|c|c|}
\hline Theme & Indicator & Unit & $\begin{array}{c}2010 \\
(2000) \\
\end{array}$ & \begin{tabular}{|c|} 
Perspective \\
1970 \\
\end{tabular} & $\begin{array}{c}\text { NL in EU } \\
2010 \\
\end{array}$ \\
\hline Population & Million inhabitants & & 16.5 & & \\
\hline \multicolumn{6}{|c|}{\begin{tabular}{|l|} 
Material welfare and well-being \\
\end{tabular}} \\
\hline \multirow[t]{3}{*}{$\begin{array}{l}\text { Consumption, } \\
\text { income }\end{array}$} & $\begin{array}{l}\text { Consumptive } \\
\text { expenditures per } \\
\text { capita, constant prices }\end{array}$ & $\begin{array}{l}\text { index } \\
(1850=100)\end{array}$ & 581 & + & + \\
\hline & $\begin{array}{l}\text { Income inequality, } \\
\text { general }\end{array}$ & $\begin{array}{l}\text { Gini coefficient } \\
0-1\end{array}$ & 0.32 & + & + \\
\hline & $\begin{array}{l}\text { Gender income } \\
\text { inequality }\end{array}$ & $\begin{array}{l}\text { \% difference } \\
\text { hourly wage } \mathrm{M} / \mathrm{F}\end{array}$ & $19 \%$ & + & - \\
\hline $\begin{array}{l}\text { Subjective } \\
\text { well-being }\end{array}$ & Satisfaction with life & Score $0-10$ & 7.8 & + & + \\
\hline \multicolumn{6}{|c|}{ Personal characteristics } \\
\hline Health & Life expectancy & year & $\begin{array}{c}\text { women } 83.0 \\
\text { men } 79.3 \\
\end{array}$ & + & $\begin{array}{c}\text { women o } \\
\text { men }+\end{array}$ \\
\hline Nutrition & $\begin{array}{l}\text { Height (military } \\
\text { conscripts) }\end{array}$ & $\mathrm{cm}$ & (183) & + & $?$ \\
\hline \multirow[t]{2}{*}{\begin{tabular}{|l} 
Housing \\
\end{tabular}} & Housing quality & $\%$ slums & $<1$ & + & 0 \\
\hline & Public water supply & $\mathrm{m}^{3} /$ capita & 120 & & \\
\hline $\begin{array}{l}\text { Physical } \\
\text { safety }\end{array}$ & Murder victims & $\begin{array}{l}\text { number per } \\
100.000 \\
\text { inhabitants. }\end{array}$ & $(1.1)$ & - & + \\
\hline Labour & Unemployment & $\%$ workforce. & 5,0 & - & + \\
\hline Education & Level of education & years & (11) & + & - \\
\hline Free time & Free time & hours per week. & 44.7 & + & $?$ \\
\hline \multicolumn{6}{|c|}{ Natural environment } \\
\hline Biodiversity & MSA & $\begin{array}{l}\% \text { original } \\
\text { biodiversity }\end{array}$ & $(63)$ & - & $?$ \\
\hline \multirow[t]{2}{*}{ Air quality } & $\mathrm{SO}_{2}$ & $\mathrm{~kg} \mathrm{SO}_{2} /$ capita & 4 & + & + \\
\hline & $\begin{array}{l}\text { Greenhouse gas } \\
\text { emissions }\end{array}$ & ton $\mathrm{CO}_{2} /$ capita & 10.6 & + & - \\
\hline Water quality & Public water supply & $\mathrm{m}^{3} /$ capita & 120 & & \\
\hline \multicolumn{6}{|c|}{\begin{tabular}{|l|} 
Institutional environment \\
\end{tabular}} \\
\hline Trust & Generalised trust & $\begin{array}{r}\% \text { population with } \\
\text { adequate trust }\end{array}$ & 67 & - & + \\
\hline $\begin{array}{l}\text { Political } \\
\text { institutions }\end{array}$ & Democracy & $\begin{array}{r}\text { Democracy-index } \\
0-100\end{array}$ & (39) & 0 & + \\
\hline
\end{tabular}

Note: The numbers in brackets are from J.L. van Zanden et al. (ed.), How was life? Global well-being since 1820 (OECD Publishing 2014) and relate to the year 2000. Numbers for these indicators measured according to the same methodology - are not available for 2010. 
Table 21.1 (continued)

\begin{tabular}{|c|c|c|c|c|c|}
\hline \multicolumn{3}{|c|}{ Dashboard well-being 'later' } & \multirow{2}{*}{$\begin{array}{c}2010 \\
(2000) \\
\end{array}$} & \multirow{2}{*}{\begin{tabular}{|c|} 
Perspective \\
1970
\end{tabular}} & \multirow{2}{*}{$\begin{array}{c}\text { NL in EU } \\
2010\end{array}$} \\
\hline & & & & & \\
\hline Natural capital & Indicator & Unit & & & \\
\hline Energy & Energy consumption & TJ /capita & 0.17 & - & - \\
\hline Non-fossil fuels & $\begin{array}{l}\text { Gross domestic } \\
\text { consumption }\end{array}$ & ton/capita & 9.8 & - & ? \\
\hline Biodiversity & MSA & $\begin{array}{l}\% \text { original } \\
\text { biodiversity }\end{array}$ & (63) & - & $?$ \\
\hline \multirow[t]{2}{*}{ Air quality } & $\mathrm{SO}_{2}$ emissions & $\mathrm{kg} \mathrm{SO}_{2} /$ capita & 4 & + & + \\
\hline & $\begin{array}{l}\text { Greenhouse gas } \\
\text { emissions }\end{array}$ & ton $\mathrm{CO}_{2} /$ capita & 10.6 & + & - \\
\hline Water & Public water supply & $\mathrm{m}^{3} /$ capita & 120 & & \\
\hline \multicolumn{6}{|l|}{ Economic capital: } \\
\hline Physical capital & $\begin{array}{l}\text { Economic capital } \\
\text { stock/capita }\end{array}$ & $\begin{array}{l}\text { index } \\
(1850=100)\end{array}$ & 1046 & + & $?$ \\
\hline Financial capital & Gross national debt & $\%$ gdp & 59 & + & 0 \\
\hline Knowledge & $\begin{array}{l}\text { Stock knowledge } \\
\text { capital }\end{array}$ & $\begin{array}{l}\text { index } \\
(2010=100)\end{array}$ & 100 & + & 0 \\
\hline \multicolumn{6}{|l|}{ Human capital: } \\
\hline Health & Life expectancy & years & $\begin{array}{c}\text { Women } 83.0 \\
\text { Men } 79.3\end{array}$ & + & $\begin{array}{c}\text { Women o } \\
\text { Men }+\end{array}$ \\
\hline Labour & Unemployment & $\%$ workforce & 5,0 & - & + \\
\hline Educational level & Schooling & years & (11) & + & - \\
\hline \multicolumn{6}{|l|}{ Social capital: } \\
\hline Trust & Generalised trust & $\begin{array}{l}\text { \% population } \\
\text { with adequate } \\
\text { trust }\end{array}$ & 67 & - & + \\
\hline Political institutions & Democracy & $\begin{array}{l}\text { democracy } \\
\text { index 0-100 }\end{array}$ & (39) & $\circ$ & + \\
\hline
\end{tabular}

Note: The numbers in brackets are from J.L. van Zanden et al. (ed.), How was life? Global well-being since 1820 (OECD Publishing 2014) and relate to the year 2000. Numbers for these indicators measured according to the same methodology - are not available for 2010.

\begin{tabular}{|l|l|l|c|c|c|}
\hline Dashboard well-being 'elsewhere' & & & \\
\hline Material Welfare & Indicator & Unit & $\mathbf{2 0 1 0}$ & $\begin{array}{c}\text { Perspective } \\
\mathbf{1 9 7 0}\end{array}$ & $\begin{array}{c}\text { NL in EU } \\
\mathbf{2 0 1 0}\end{array}$ \\
\hline Consumption, income & Development aid & $\%$ gdp & 0,8 & 0 & 0 \\
\hline Natural capital & & & & & \\
\hline Natural capital & Import of raw materials & ton/capita & 12,5 & 0 & - \\
\hline
\end{tabular}

(continued) 
Table 21.1 (continued)

\begin{tabular}{|c|l|}
\hline+ & $\begin{array}{l}\text { Not problematic/was not problematised from the perspective of 1970. Present-day } \\
\text { perspective: The Netherlands is in good shape because it belongs among the } \\
\text { nine highest-scoring EU member states. }\end{array}$ \\
\hline- & $\begin{array}{l}\text { Problematic from the perspective of 1970. Present-day perspective: the situation is } \\
\text { problematic because the Netherlands belongs among the nine lowest-scoring EU } \\
\text { member states. }\end{array}$ \\
\hline O & $\begin{array}{l}\text { Under discussion: different opinions about the scale and nature of the problems. } \\
\text { Present-day perspective: No evaluation in terms of problematic or not problematic. } \\
\text { The Netherlands scores in the middle group of the 27 EU member states. }\end{array}$ \\
\hline$?$ & Unknown \\
\hline
\end{tabular}

Remark 1: For present days perspective the table indicates the Netherlands position within the EU-27 (see legend)

Remark 2: Public water supply is left blank; this indicator became irrelevant as an indicator for water quality

Source: See note 23 of Chap. 2; The position of The Netherlands in EU derived from Monitor Duurzaam Nederland 2014. Indicatorenrapport (Den Haag 2014), 158-169. Numbers from years between 2010 and 2013

The problems pertain above all to the capitals, in other words to the resources for 'later.' This does not concern economic or social capital - these are in reasonable and even good shape - but rather natural and human capital.

In previous chapters human capital has barely been mentioned. An important issue is the level of education of the Dutch populace. To be sure, the level of education measured as years of schooling has increased, but the number of school dropouts is substantial and the quality of primary and secondary education is declining, judging by the scores of Dutch pupils on international comparative tests. ${ }^{43} \mathrm{~A}$ welleducated populace is important for labour productivity and the material welfare of a country. In addition, education also to a great extent determines the quality of an individual's personal life. ${ }^{44}$ The well-educated get the better jobs, have a higher income, are healthier and live longer. The less-educated are vulnerable in the labour market, change jobs more often, have to work more years and have a materially less secure existence. Social inequality is not only a question of income but also manifests itself in these kinds of aspects. Nowadays school diplomas are the main determinant of this dimension of inequality.

Of the four capitals, natural capital is the most problematic. ${ }^{45}$ In the 1990 s, with its research and policy experience, the Netherlands set the tone for European policy that was rolled out from 2000 on, but the Netherlands itself, paradoxically enough, seemed barely able to meet the norms it had implicitly set for itself. The Netherlands

\footnotetext{
${ }^{43}$ Monitor Duurzaam Nederland 2011, 58.

${ }^{44}$ Also see: Kwaliteit van leven in Nederland (Centraal Bureau voor de Statistiek, Den Haag 2015), $56-58$.

${ }^{45}$ Monitor Duurzaam Nederland 2011, 51.
} 
is among the EU countries with the highest per capita energy consumption, the lowest investment in renewable energy sources and the highest per capita emissions of greenhouse gases. The nutrient surplus in the soil is among the biggest in Europe. Despite many improvements, Dutch surface water nowhere meets the European quality norm. And the Netherlands still has little forest and nature compared with other European countries. Biodiversity in the countryside and in nature preserves is chronically under pressure.

There are also problems with the degree to which the Netherlands places a burden on nature and environment "elsewhere. ${ }^{46}$ It belongs among the EU countries with the biggest per capita import of bio-raw materials and mineral and fossil subsoil resources. The raw materials that are imported into the Netherlands from developing countries are a special problem. To be sure, this trade creates incomes in developing countries, but an analysis by the World Bank shows that these local incomes are generally spent in consumption and frequently to the benefit of a small elite. There is also the problem of depletion, loss of biodiversity and often also of a one-sided economic structure. ${ }^{47}$ The Netherlands has shifted some of its sustainability problems elsewhere.

On the other hand, Dutch exports and hence the Dutch products consumed in other countries contribute to problems in the Netherlands. For example the massive export of meat is associated with sustainability problems in cattle husbandry and the bio-industry.

This short evaluation confirms what has emerged in this and preceding chapter: The most import sustainability issues for the coming decades are energy, raw materials and biodiversity. In the Epilogue we summarise the historical process that has led to these problems. We also investigate, from a historical perspective, the concept of 'circular economy,' a notion that is regarded as the most important option for a way out of our present-day predicament.

\section{Literature}

Anonymus, (1989a, november 4). 'Nijpels hoopt op afspraken tijdens milieuconferentie' in NRC Anonymus, (1989b, november 7). 'Milieuconferentie begint in sfeer van onenigheid, Nederland vraagt om hulp voor Derde Wereld' in Nederlands dagblad

Arnoldussen, T. (2016). The Social Construction of the Dutch Air Quality Clash. How Road Expansions Bit the Dust Against Particulate Matter. 125-64. The Hague: Eleven International Publishing.

\footnotetext{
${ }^{46}$ Monitor Duurzaam Nederland 2011, 60-63.

${ }^{47}$ Monitor Duurzaam Nederland 2011, 62-63.
} 
Bijl, R. et al. (2015). De sociale staat van Nederland 2015. 221-222. Den Haag: Sociaal en Cultureel Planbureau.

Bouwens, B. and Dankers, J. (2012). Tussen concurrentie en concentratie. Belangenorganisaties, kartels, fusies en overnames. 205. Amsterdam: Uitgeverij Boom

Bouwer, K., Klaver, J., and de Soet, M. (1983). Nederland Stortplaats, een Milieukundig en Geografische Visie op het Afvalprobleem. Nijmegen: Ekologische uitgeverij.

Buijsman, E. (2008). 'Gisteren, Vandaag, Morgen, Een Terugblik op het Probleem van Zure Regen,' Studium 4: 251-68

Centraal Bureau voor de Statistiek (2011). Monitor Duurzaam Nederland 2011. Den Haag/ Heerlen: Centraal Bureau voor de Statistiek

Centraal Bureau voor de Statistiek (2014). Monitor duurzaam Nederland 2014: Indicatorenrapport. Den Haag/Heerlen: Centraal Bureau voor de Statistiek.

Centraal Bureau voor de Statistiek (2015). Kwaliteit van leven in Nederland. 56-58. Den Haag: Centraal Bureau voor de Statistiek

Cramer, J. (2014) Milieu. Amsterdam: Amsterdam University Press.

Dinkelman, G.H. Verzuring en Broeikaseffect, de Wisselwerking tussen Problemen en Oplossingen in het Nederlandse Luchtverontreinigingsbeleid (1970-1994). Amsterdam: Universiteit van Amsterdam.

Duyvendak, W. (2011) Het Groene Optimisme, Het Drama van 25 Jaar Klimaatpolitiek. Amsterdam: Bert Bakker.

Högselius, P., Kaijser, A. and van der Vleuten, E. (2016). Europe's Infrastructure Transition, Economy, War, Nature, vol. 4, Making Europe: Technology and Transformations, 1850-2000. Basingstoke / New York: Palgrave Macmillan.

Jongman, Rob H.G. (1995). 'Nature Conservation Planning in Europe: Developing Ecological Networks' in Landscape and Urban Planning 32: 196-183.

Kamer van Koophandel (1989). Beleidsplan Provinciaal Samenwerkingsorgaan Kamer van Koophandel Noord-Brabant Beleidsplan 1989, 11 in Archief Provinciaal Bureau Kamers van Koophandel in Noord-Brabant, BHIC 1157, map 44.

Kamer van Koophandel (1991). Jaarverslag Kamer van Koophandel Noordoost-Brabant 1991.

Lintsen, H. and Korsten, J. (2017). De veerkracht van de Brabantse economie. De Kamers van Koophandel en de kracht van netwerken [1840-2015]. 134-139. Hilversum: Stichting Zuidelijk Historisch Contact \& Uitgeverij Verloren

Peet, J. and Nijhof, E. (2015). Een voortdurend experiment. Overheidsbeleid en het Nederlandse bedrijfsleven (Uitgeverij Boom, Amsterdam 2015), 199-205.

Planning Bureau for the Environment (2017). Analyse regeerakkoord Rutte-III: effecten op klimaat en energie 3009, 33. Den Haag: Planbureau voor de Leefomgeving.

Reichow, A. (2015). Effective regulation under conditions of scientific uncertainty: How collaborative networks contribute to occupational health and safety regulation for nanomaterials. 37-38. Enschede: UT Twente

Salverda, W. et al. (2013). Nederlandse ongelijkheid sinds 198. Loonvorming, overheidsbeleid en veranderde samenstelling van huishoudens. Amsterdam: Amsterdam Institute for Advanced Labour Studies/ University of Amsterdam

Schuyt, K. and Taverne, E. (2000). 1950. Welvaart in zwart-wit. 40-41. Den Haad: Sdu Uitgeverij Siraa, H.T., van der Valk, A.J. and Wissink, W.L. (1995). Met het Oog op de Omgeving. Het Ministerie van Volkshuisvesting, Ruimtelijke Ordening en Milieubeheer, 1965-1995. 244-67. Den Haag: SDU Uitgeverij.

van Baalen, Carla et al. (2005). Koning Beatrix aan het Woord, 25 Jaar Troonredes, Officiële Redevoeringen en Kersttoespraken. Den Haag: Sdu Uitgeverij.

van Campen, C. et al. (2012) Sturen op geluk. Geluksbevordering door nationale overheden, gemeenten en publieke instellingen. 17-23. Den Haag: Sociaal en Cultureel Planbureau. 
van der Cammen, H. and de Klerk, L. (2003). Ruimtelijke Ordening, van Grachtengordel tot VinexWijk. 252-53. Utrecht: Het Spectrum

van der Sluijs, J. P., van Est, R. and Riphagen, M. (2010). Room for Climate Debate, Perspectives on the Interaction between Climate Politics, Science and Media. 18-20. The Hague: Rathenau Instituut

van Zanden J.L., Griffiths, R.T. (1989). Economische geschiedenis van Nederland in de $20^{e}$ eeuw. 48-49. Utrecht: Aula.

Open Access This chapter is licensed under the terms of the Creative Commons Attribution 4.0 International License (http://creativecommons.org/licenses/by/4.0/), which permits use, sharing, adaptation, distribution and reproduction in any medium or format, as long as you give appropriate credit to the original author(s) and the source, provide a link to the Creative Commons license and indicate if changes were made.

The images or other third party material in this chapter are included in the chapter's Creative Commons license, unless indicated otherwise in a credit line to the material. If material is not included in the chapter's Creative Commons license and your intended use is not permitted by statutory regulation or exceeds the permitted use, you will need to obtain permission directly from the copyright holder.

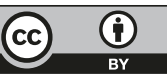

